\title{
A Comparative Analysis of the Policy Development Function of U.S. State Party Organizations
}

\section{Joel Paddock, Southwest Missouri State University}

Platforms provide a guide to a party's ideological location at a particular time. As such, they can be a useful tool for comparing interparty and intraparty differences over policy alternatives at the subnational level. This analysis of the recent platforms of 40 state Democratic parties and 34 state Republican parties, patterned after Ginsberg's $(1972,1976)$ framework, revealed considerable ideological decentralization (across-state intraparty differences) within both parties. Further analysis of platform contents in relationship to Erikson. Wright, and McIver's (1993) research revealed weak correlations between the ideological content of platforms and the ideological orientations of state electorates, state elected officials, state party activists, and party identifiers, respectively.

Despite the fact that one of the most distinguishing features of the American party system is its decentralization, surprisingly little research has compared the public policy alternatives put forth by state party organizations. Public policy development frequently is mentioned as a central function of party organizations. We know very little, however, about the nature and extent of policy differences among American state parties. There is an extensive literature on the resurgence of state party organizations and their organizational adaptation to a new style of electoral politics that suggests that state parties have become more professionalized and active in recent years (e.g., Cotter et al. 1984; Huckshorn et al. 1986). The policy development function of these organizations warrants further scholarly inquiry.

Traditionally, the central medium through which parties have presented public policy alternatives to the voters has been the party platform, which is "the principal official statement of party principles and policies" (Porter and Johnson 1970, vi). Party platforms sometimes are belittled as meaningless acts of political rhetoric that are rarely read and just as rarely followed once the party candidates are in office.

Another perspective, however, suggests that while voters generally do not read platforms, the content of the pledges usually reaches them through less direct means and that once in office parties do a reasonably good job of delivering on their pledges (Pomper 1967, 1968; David 1971; Monroe 1983;

JOEL PADDOCK is Associate Professor of Political Science at Southwest Missouri State University.

The American Review of Politics, Vol. 15, Summer, 1994: 291-303

(9)1994 The American Review of Politics 
Budge and Hofferbert 1990). Party platforms, Pomper $(1968,203)$ writes, "are a meaningful guide to party action." As the major statement of a party's principles and policies, they may indicate trends in the thinking of at least some elements of the party, and changes in the intra-party balance of power. Platform statements, Ginsberg $(1972,607)$ writes, "represent an amalgamation and distillation of the principles, attitudes, appeals, and concerns of the party as a whole, or at least its dominant factions."

While platforms clearly do not reflect the attitudes of all of a party's activists, they provide a guide to a party's ideological mainstream at a particular time. As such, they can be a useful tool for scholars interested in comparing inter-party and intra-party differences over policy alternatives at the subnational level, a comparison that should be of theoretical concern. Decentralized parties, it is argued, can accommodate a wide variety of interests within the broader national party organizations. On the other hand, a body of literature contends that party organizations have become more nationalized, suggesting a reduction in intra-party policy differences and greater cooperation between the component parts (national, state, and local organizations) of the parties (Bibby 1979; Kayden 1980; Epstein 1982; Conway 1983; Kayden and Mahe 1985; Wekkin 1984, 1985; Reichley 1985; Frantzich 1986; Herrnson and Menefee-Libey 1990). Studying the content of state party platforms can provide scholars with insights into the degree of intra-party and inter-party policy heterogeneity or homogeneity. Are the policy positions of state parties relatively homogeneous, or do their platforms reflect a broader spectrum of policy alternatives? Are state Democratic and Republican platforms ideologically similar or distinct? What types of states exhibit the highest levels of inter-party ideological differences? In this paper a content analysis of state party platforms will be used to address these questions.

\section{Content Analyzing State Party Platforms}

A 1992 national survey of state party organizations found that most parties (40 Democratic, 34 Republican) had drafted a platform within the past four years. Some parties draft the documents every two years; others draft them every four years. State platforms are drafted in presidential election years, presidential mid-term election years, as well as odd-numbered years. Although most platforms in this analysis came from 1992, a few date to 1989,1990 , and 1991 . The most recently drafted platform from each state party was used (although no platforms prior to 1988 were considered).

A reading of a representative sample of platforms revealed that most statements could be classified according to the general categories employed 
by Ginsberg $(1972,1976)$. Although Ginsberg's analysis was of national platforms, the categories are useful to the analysis of state platforms. Because of their generality, the categories allowed a number of diverse statelevel policies to be coded and compared. The "Social Issue" was added to Ginsberg's categories because of its particular relevance to contemporary American politics.

The unit of analysis was the paragraph. The platforms were divided into paragraphs and each paragraph was classifed on the basis of the predetermined categories. Each paragraph could potentially receive one score for each category, although because of the thematic nature of the platforms, most paragraphs only fit in one or two categories. A five point scale was developed for each category to measure the ideological orientations of the platform statements. The five-point scale measures ideological direction and the degree of policy specificity. A "1" is a stronger, more issue specific, statement in a particular direction than a "2". Hence, the five point scale should be viewed as a continuum on which " 3 " is a vague or neutral position. The further one moves from the center, the greater is the policy specificity in a particular ideological direction. The following is a brief synopsis of the seven major categories and the ideological scale for each category.

- Capitalism: The aggregation of wealth and control over the distribution of wealth by the private sector.

(Scores of) 1 and 2 indicate commitment to the values of free enterprise as a means of distributing benefits and burdens, and hostility to government intervention in the private economy;

(Scores of) 4 and 5 indicate orientation toward public sector action to control the private sector's aggregation of wealth.

-Redistribution: the reallocation of advantages in favor of the disadvantaged. 1 and 2 indicate opposition to state policies redistributing advantages; 4 and 5 indicate advocacy of public sector action to redistribute advantages.

-Internal Sovereignty: the exercise of the power and increase of the role of the national government vis-à-vis the states and localities.

1 and 2 indicate opposition to federal intervention in state and local affairs (a states' rights orientation);

4 and 5 indicate support for a larger role for the national government vis-à-vis the states and localities. 
-Labor: workers, organized labor, and policies regulating unions and the workplace.

1 and 2 indicate negative orientation toward organized labor, opposition to policies supported by unions (e.g., unemployment compensation, worker safety), and/or support for policies opposed by unions (e.g., right-to-work laws);

4 and 5 indicate positive orientation toward organized labor and policies they support.

-Universalism: equality of rights and privileges for domestic minorities and women.

1 and 2 indicate general opposition to public policies requiring private and/or public agencies to alter their behavior for the purpose of promoting equal rights for minorities and/or women;

4 and 5 indicate support for policies promoting equality for minorities and/or women.

- Social Issues: the use of the coercive power of the state to regulate private behavior based upon traditional standards or the desire to promote social order.

1 and 2 indicate support for preserving traditional values, standards of behavior, and social order through the use of the state's power;

4 and 5 indicate the promotion of free expression and social experimentation (e.g., right to protest, right of abortion, right to privacy) and opposition to attempts to use the power of the state to limit noneconomic freedoms.

-Foreign/Defense: actions concerning relations with foreign objects and national security policy.

1 and 2 indicate advocacy of the use of military force or the threat of military force, rather than diplomacy, to achieve American interests in the world;

4 and 5 indicate advocacy of the use of diplomacy, as opposed to military force, to achieve American objectives in the world. ${ }^{1}$

Because of the amount of subjective coding involved, care was taken to ensure coder reliability. An in-depth discussion of the precise nature of the categories, subcategories, and ideological scales was provided to the coders, but has been condensed for this paper because of space limitations. A comparison was made between the results of the two coders using a random sample of 15 percent of the platforms. Inter-coder reliability scores averaged .90 overall. 


\section{Findings}

The extent of inter-party policy differences can be measured in two ways: differences over the relative emphasis each party gave to the general policy areas, and ideological differences as measured by the five-point scale in each policy area. Table 1 summarizes the relative emphasis each party gave to the seven general categories. The figures are simply the percentages of the total content of the platforms that were devoted to each of the issue domains. The percentages do not add up to 100 percent because the platforms had statements that did not fit into any category.

The most obvious difference in the two parties' agendas is their relative emphasis on redistribution and the social issue. The Democratic state parties mentioned redistributive issues almost twice as much as did Republican organizations, while the Republican parties stressed social issues almost twice as much as did the Democrats. Given the coalitional strategies of the two parties, these differences are not surprising. The Democrats have relied, in part, on a class-based coalition since the New Deal. Many redistributive issues fit into this coalitional strategy. Likewise, many Republican organizations have courted the social right since the late 1960s and early 1970s. The greater Republican preoccupation with the social issues is a likely reflection of this coalitional strategy. Also not surprisingly, the Democrats placed greater emphasis than the Republicans on labor and universalism; labor unions, women, and minorities clearly have been important components of the Democratic coalition in recent decades.

Table 2 summarizes the aggregate mean ideology scores for both parties, and the inter-party ideological differences between the parties. In the aggregate, clear ideological differences distinguish the parties in each of the

\section{Table 1. The Proportion of Platform Statements Devoted to Each Category}

\begin{tabular}{lcc}
\hline & Democrats & Republicans \\
\hline Capitalism & $38 \%$ & $39 \%$ \\
Redistribution & 21 & 12 \\
Internal Sovereignty & 5 & 5 \\
Labor & 5 & 2 \\
Universalism & 8 & 4 \\
Social Issue & 10 & 19 \\
Foreign Defense & 6 & 5 \\
\hline
\end{tabular}


Table 2. Aggregate Ideology Scores and Inter-Party Ideological Differences

\begin{tabular}{lccc}
\hline & Democrats & Republicans & Difference \\
\hline Capitalism & 3.39 & 2.51 & .88 \\
Redistribution & 3.56 & 2.69 & .87 \\
Internal Sovereignty & 3.54 & 2.49 & 1.05 \\
Labor & 3.70 & 2.35 & 1.35 \\
Universalism & 3.66 & 2.88 & .78 \\
Social Issue & 3.42 & 2.25 & 1.17 \\
Foreign/Defense & 3.57 & 2.46 & 1.11 \\
Overall & 3.48 & 2.48 & 1.00 \\
\hline
\end{tabular}

seven categories. Democrats and Republicans differed the most on labor issues and the least on universalism. The overall inter-party difference of 1.00 (on a five-point scale) hardly demonstrates ideological polarization, but does show that the parties come from separate ideological "centers of gravity." These numbers suggest that, at least in the aggregate, the state parties were not completely non-ideological organizations hugging the ideological middle ground, nor were they ideologically polarized. Rather, it appears that through different coalitional strategies and the accommodation of different interests they reached their respective positions moderately to the left and right of the center of the ideological continuum. Aggregate figures, however, can be misleading. Some state party organizations might be ideologically polarized, while others might be centrist. It is necessary to examine the data from the individual state parties.

Table 3 summarizes the overall average ideology scores for the forty state Democratic parties and thirty-four Republican organizations. The thirty states in which both parties drafted platforms are ranked on the basis of inter-party ideological differences (the difference between the overall mean Democratic and Republican ideology scores for each state). The mean ideology scores of the other state Democratic and Republican parties are listed at the bottom of Table 3 .

The aggregate figures in Tables 1 and 2 clearly mask the vast differences within the two parties, as well as between the two parties in several states. The range of overall ideology scores in each party is substantial (Republicans 1.27, Democrats .94). Although there seems to be an ideological "center of gravity" around the overall mean in each party, there are significant differences between the parties' two flanks. The most liberal Democratic state parties (e.g. Washington, Minnesota, Maine, and 


\section{Table 3. Mean Ideology Scores and Inter-Party Differences for Democratic and Republican State Organizations}

\begin{tabular}{|c|c|c|c|}
\hline & $\begin{array}{l}\text { Democratic } \\
\text { Mean }\end{array}$ & $\begin{array}{l}\text { Republican } \\
\text { Mean }\end{array}$ & $\begin{array}{l}\text { Inter-Party } \\
\text { Difference }\end{array}$ \\
\hline Washington & 4.01 & 2.05 & 1.96 \\
\hline Oregon & 3.79 & 2.06 & 1.73 \\
\hline Wisconsin & 3.90 & 2.25 & 1.65 \\
\hline Iowa & 3.83 & 2.19 & 1.64 \\
\hline Minnesota & 4.01 & 2.35 & 1.57 \\
\hline Alaska & 3.52 & 2.06 & 1.46 \\
\hline California & 3.56 & 2.12 & 1.44 \\
\hline Texas & 3.48 & 2.17 & 1.31 \\
\hline Oklahoma & 3.29 & 1.99 & 1.30 \\
\hline Maine & 3.92 & 2.64 & 1.28 \\
\hline Nevada & 3.52 & 2.30 & 1.22 \\
\hline Montana & 3.61 & 2.40 & 1.21 \\
\hline Idaho & 3.50 & 2.31 & 1.19 \\
\hline North Carolina & 3.57 & 2.51 & 1.06 \\
\hline Nebraska & 3.57 & 2.56 & 1.01 \\
\hline Overall Mean & 3.48 & 2.48 & 1.00 \\
\hline Florida & 3.52 & 2.53 & .99 \\
\hline Vermont & 3.62 & 2.63 & .99 \\
\hline Wyoming & 3.29 & 2.35 & .94 \\
\hline Missouri & 3.39 & 2.50 & .89 \\
\hline Illinois & 3.39 & 2.53 & .86 \\
\hline Utah & 3.10 & 2.25 & .85 \\
\hline West Virginia & 3.40 & 2.61 & .79 \\
\hline North Dakota & 3.44 & 2.67 & .77 \\
\hline South Carolina & 3.20 & 2.50 & .70 \\
\hline Indiana & 3.19 & 2.70 & .49 \\
\hline Kansas & 3.46 & 3.00 & .46 \\
\hline South Dakota & 3.42 & 2.96 & .46 \\
\hline New Hampshire & 3.31 & 2.86 & .45 \\
\hline New Jersey & 3.31 & 2.93 & .38 \\
\hline Rhode Island & 3.43 & 3.26 & .17 \\
\hline \multicolumn{4}{|c|}{$\begin{array}{l}\text { Overall ideology scores for states in which only one party drafted a platform: Demo- } \\
\text { crats-Arizona 3.74, Massachusetts 3.71, Colorado 3.43, Michigan 3.38, Connecticut } \\
\text { 3.35, New Mexico 3.31, Arkansas 3.30, Delaware 3.24, Mississippi 3.24, Georgia 3.07; } \\
\text { Republicans-Ohio 2.85, New York 2.58, Pennsylvania 2.45, Hawaii 2.31. }\end{array}$} \\
\hline
\end{tabular}


Wisconsin) are clearly different than the more moderate organizations (e.g. South Carolina, Indiana, Utah, and Georgia). Even more pronounced, the conservative Republican state organizations (e.g. Oklahoma, Washington, Alaska, and Oregon) are substantially different than the party's moderate organizations (e.g. Rhode Island, Kansas, South Dakota, and New Jersey). Lacking longitudinal data, we cannot determine any movement toward or away from ideological nationalization. However, the 1992 data do suggest the existence of a significant amount of ideological decentralization in both parties.

The degree of ideological decentralization in each party can be determined by developing a measure of intra-party differences. The extent of intra-party differences can be conceived of as the average amount of variation around the mean of the state parties. Standard deviations were calculated to determine what policy areas caused the greatest amount of intraparty ideological dispersion. Table 4 summarizes the standard deviation for each issue. The standard deviations are based on the mean ideology scores.

Both parties experienced about the same level of intra-party differences. The Republicans were most divided on labor issues and matters involving the role of the federal government, while the Democrats had the greatest disagreement on social and foreign policy issues. The relatively high Democratic intra-party differences on the social issue were less the result of policy disagreements than of policy emphasis. The more conservative parties on the social issue emphasized criminal justice issues and largely ignored issues such as abortion, alternative lifestyles, etc. The more liberal parties on the social issue focused primarily on freedom of expression, right to privacy, and lifestyle issues.

Table 4. Standard Deviations of the Seven Categories

\begin{tabular}{lcc}
\hline & Democrats & Republicans \\
\hline Capitalism & .25 & .31 \\
Redistribution & .25 & .33 \\
Internal Sovereignty & .37 & .41 \\
Labor & .32 & .41 \\
Universalism & .36 & .39 \\
Social Issue & .41 & .32 \\
Foreign Defense & .39 & .37 \\
Overall & .34 & .36 \\
\hline
\end{tabular}


It is notable that the most salient issues on the parties' respective agendas (capitalism and redistribution for the Democrats, capitalism and the social issue for the Republicans) were the least divisive. None of the issues, however, stands out as being particularly more divisive than the others. The overall standard deviation figures do not suggest a great degree of intraparty differences. Similar data need to be gathered over an extended period of time to determine changes in the relative intra-party differences over time. Such data would be useful in addressing the broader theoretical issue of party decentralization versus party nationalization.

Although the aggregate figures from Table 2 did not suggest ideological polarization, the figures in Table 3 indicate that in some states inter-party ideological differences were quite substantial. The states with the highest inter-party differences run contrary to the traditional description of American parties as non-ideological and centrist. It is interesting to note that the top seven states in Table 3 (Washington, Oregon, Wisconsin, Iowa, Minnesota, Alaska, and California) have similar traditions of issue-oriented party activism, and, according to Daniel Elazar, predominantly moralistic subcultures (Elazar 1984; Mayhew 1986). Similarly, several of the states with the lowest inter-party differences (e.g. Rhode Island, New Jersey, Indiana, West Virginia) have traditions of patronage-oriented party organizations and individualistic subcultures (Elazar 1984; Mayhew 1986).

One might speculate that in the states with traditions of issue-oriented non-hierarchical party organizations, the party machinery was more easily penetrated by "amateur," issue-oriented activists. In the states with traditions of patronage-oriented party organizations, pragmatic, "professional" activists were more likely to predominate in the formation of the party platform. A major difficulty here is distinguishing between genuine amateur activism on one hand, and parties responding to an ideologically polarized electorate on the other. Did the Washington parties, for example, experience genuine amateur activism, or were they merely responding to an electorate that was more ideologically polarized than, for example, in Rhode Island?

Fully addressing this question will require a much more in-depth analysis of the platform-writing process in each of the states. We do not know enough about how this process differs from state to state, or about the types of party activists involved in writing platforms in different states to fully understand why inter-party platform differences are greater in some states than in others.

Although more work clearly needs to be done on the types of activists involved in writing platforms, and the relationship between platform content and public opinion, a tentative analysis (using existing data sources) can be made to assess the relationship between the ideological orientations of state 
platforms and the ideology of state electorates, party identifiers, party activists, and elected officials. How strongly do the ideological orientations of state party platforms correlate with state public opinion and the ideology of state party identifiers, activists, and elected officials?

Erikson, Wright and McIver (1993) provide useful state-level measures of the ideology of voters and party activists that can be compared with the figures from Table 3. Using state-level CBS News-New York Times polls between 1976 and 1988, they derived ideology measures for the overall state electorate and for Democratic, Republican, and Independent identifiers in forty-eight states. A measure of the attitudes of state elected officials in each party was derived from CBS News-New York Times surveys of congressional candidates between 1974 and 1982, as well as a 1974 survey of state legislators carried out by Uslaner and Weber (1977). The ideology of state party activists was measured by a 1980 survey of Republican national convention delegates that was collected by Miller and Jennings (1987).

Table 5 summarizes the correlations between the ideological orientations of the Republican and Democratic platforms and the ideological scores of state electorates, Republican and Democratic identifiers, Republican and Democratic elected officials and Republican and Democratic state party activists (Erikson, Wright, and McIver 1993). The correlations for the Republicans are based only on the thirty-four states from which Republican platforms were obtained (see Table 3). The correlations for the Democrats are based only on the forty states from which Democratic platforms were obtained (see Table 3). Nebraska and Nevada are not included in the correlations between state platforms and state party activists and elected office holders; data on activists and elected officials from these states were not obtained by Erikson, Wright and McIver (1993).

The figures in Table 5 show a weak relationship between state electorates and state party platforms in both parties. The ideological orientations of Republican platforms weakly correlate with the ideological orientations of Republican elected officials and state party activists. The ideological orientation of Republican identifiers has the strongest correlation with Republican platforms, but even this correlation is relatively weak. The Democratic platforms more strongly correlate with the ideology of Democratic elected officials and party activists. However, the Democratic platforms correlate less strongly with Democratic identifiers. Based on these data, it appears that in many state parties public opinion was not a major consideration in framing the party platform. In the Republican party it appears that the activists who drafted the platforms were ideologically different than the activists who served as county chairs and as national convention delegates. There appears to be a closer relationship, however, 
between Democratic party elites (county chairs and national convention delegates) and the activists who drafted the state platforms.

The figures in Table 5 re-emphasize the point that the policy alternatives offered in state party platforms provide only one measure (among potentially many) of the ideological orientations of state party organizations. One also could measure state party ideology by surveying the attitudes of party identifiers in the state electorate, local or state party committee members, national convention delegates, or elected officials from the state party. The extent to which the policy alternatives offered in state party platforms reflect the state party as a whole will remain unclear until we (1) gain a better understanding of platform-formation processes in the states; (2) more fully develop measures of the attitudes of state parties-in-the-electorate and state party activists; and (3) more fully address the conceptual issue of who or what constitutes a state party organization.

\section{Table 5. Correlations Between the Ideological Orientations of State Party Platforms and State Electorates, State Elected Officials, State Party Activists, and State Party Identifiers}

\begin{tabular}{lcc}
\hline & $\begin{array}{c}\text { Republican } \\
\text { Platforms }\end{array}$ & $\begin{array}{l}\text { Democrat } \\
\text { Platforms }\end{array}$ \\
\hline Electorate & .17 & .33 \\
Repub. Elected Officials & .27 & \\
Repub. Activists & .28 & \\
Repub. Identifiers & .44 & .53 \\
Demo Elected Officials & & .64 \\
Democratic Activists & & .25 \\
Democratic Identifiers & & \\
\hline
\end{tabular}

\section{Conclusion}

The findings in this analysis are tentative. We have little understanding of the process of platform construction in the American states. In some states the platform may be a document on which the party's gubernatorial nominee runs his/her campaign. As such, the platform may be written by a small number of individuals closely tied to the gubernatorial nominee. In other states, the process may be open to a variety of party activists representing different interests and factions within the party. Hence, we must be cautious 
in attributing certain characteristics of the party platform to the state party as a whole.

In addition, figures from one election do not provide a longitudinal perspective. In order to address the theoretical issue of growing ideological nationalization, data from an extended time period must be compiled. Such data could include not only content analyses of party platforms, but surveys of party identifiers in the states and state party activists. Our understanding of the ideological orientations of state party organizations (and even the conceptual problem of identifying who represents or constitutes a state party organization) is quite limited. Clearly, more scholarly work needs to be done on the role played by state party organizations in defining the alternatives of public policy.

\section{NOTE}

${ }^{1}$ As Wittkopf (1987) notes, foreign policy attitudes can be conceptualized by two, rather than one dimension of conflict: support for and opposition to cooperative internationalism, and support for and opposition to militant internationalism. In order to maintain consistency with the other categories in this analysis (which have one dimension of conflict), the Foreign/Defense category measures only the militant internationalism dimension. While this does not capture the depth of the foreign policy debate, it allows for operational consistency with an issue that was not a major part of the state party platforms.

\section{REFERENCES}

Bibby, John F. 1979. Political Parties and Federalism: The Republican National Committee. Publius 9: $229-236$.

Budge, Ian and Richard I. Hofferbert. 1990. Mandates and Policy Outputs: U.S. Party Platforms and Federal Expenditures. American Political Science Review 84: 111-131.

Conway, Margaret. 1983. Republican Political Party Nationalization, Campaign Activities, and Their Implications for the Party System. Publius 13: 1-17.

Cotter, Cornelius P., James I. Gibson, John F. Bibby, and Robert J. Huckshorn. 1984. Party Organizations in American Politics. New York: Praeger.

David, Paul T. 1971. Party Platforms as National Plans. Public Administration Review 31: 303-315. Elazar, Daniel J. 1984. American Federalism: A View From the States. New York: Harper and Row. Epstein. Leon. 1982. Confederations and Party Nationalization. Publius 12: 67-102.

Erickson, Robert S., Gerald C. Wright, Jr. and John P. Mclver. 1989. Political Parties, Public Opinion, and State Policy in the United States. American Political Science Review 83: 729750 .

1993. Statehouse Democracy: Public Opinion and Policy in the American States. New York: Cambridge University Press.

Frantzich, Stephen. 1986. Republicanizing the Parties: The Rise of the Service Vendor Party. Paper presented at the 1986 Annual Meeting of the Midwest Political Science Association, Chicago, April 10-12. 
Ginsberg. Benjamin. 1972. Critical Elections and the Substance of Party Conflict: 1844-1968. Midwest Journal of Political Science 16: 603-626.

1976. Elections and Public Policy. American Political Science Review 70: 41-49.

Herrnson, Paul S., and David Menefee-Libey. 1990. The Dynamics of Party Organizational Strength. Midsouth Political Science Journal 11: 3-30.

Huckshorn, Robert J., James L. Gibson, Cornelius P. Cotter, and John F. Bibby. 1986. Party Integration and Party Organizational Strength. Journal of Politics 48: 976-991.

Kayden. Xandra. 1980. The Nationalizing of the Party System. In Michael Malbin, ed., Parties, Interest Groups and Campaign Finance Laws. Washington: American Enterprise Institute. and Eddie Mahe, Jr. 1985. The Party Goes On. New York: Basic Books.

Mayhew, David. 1986. Placing Parties in American Politics. Princeton: Princeton University Press.

Miller, Warren E., and M. Kent Jennings. 1987. Parties in Transition: A Longitudinal Study of Party Elites and Party Supporters. New York: Russell Sage.

Monroe. Alan D. 1983. American Party Platforms and Public Opinion. American Journal of Political Science 27: 27-42.

Pomper, Gerald M. 1967. If Elected, I Promise: American Party Platforms. Midwest Journal of Political Science 29: 535-566. 1968. Elections in America. New York: Dodd, Mead and Company.

Porter, Kirk H. and Donald Bruce Johnson. 1970. National Party Platforms, 1840-1968. Urbana: University of Illinois Press.

Reichley, A. James. 1985. The Rise of National Parties. In John Chubb and Paul Peterson, eds., The New Direction in American Politics. Washington: The Brookings Institution.

Uslaner. Eric M. and Ronald E. Weber. 1977. Patterns of Decision Making in State Legislatures. New York: Praeger.

Wekkin, Gary D. 1984. National-State Party Relations: The Democrats' New Federal Structure. Political Science Quarterly 99: 45-72.

1985. Political Parties and Intergovernmental Relations in 1984: Consequences of Party Renewal for Territorial Constituencies. Publius 15: 19-37.

Wittkopf, Eugene R. 1987. Elites and Masses: Another Look at Attitudes Towards America's World Role. International Studies Quarterly 31:131-159.

Wright, Gerald C., Jr., Robert S. Erikson, and John P. McIver. 1985. Measuring State Partisanship and Ideology With Survey Data. Journal of Politics 47: 469-489. 